\title{
Functions of Education which Contributes to the Reproduction and Transformation of Values. Stabilizing Regional Interethnic Relations
}

\author{
Marina A. Cherkasova \\ Svetlana G. Bayurova \\ Russian state Social University, Kamensk-Shakhtinsk \\ Email: rusciense@mail.ru,kamensk@rgsu.net
}

Doi:10.5901/mjss.2015.v6n3s1p356

\begin{abstract}
With the onset of the new century the paradigm of social development of the Russian society, which in 1993 was named in the Constitution as social, has changed. Such concepts as social policy, social development, social institutions have become popular not only in journalism but also in the speeches of public authorities. Education being one of the most numerous social institutions, are developing on the basis of continuity. The need to resolve inter-ethnic relations, worsened after the collapse of the Soviet Union, highlights the problem of search of pedagogical techniques that promote the development of tolerance, liberal attitude towards religion, intercultural communication, capacity for dialogue both in each individual and in society. The low level of education, according to many scientists, is the cause of the instability of the views of young people. Namely in the youth environment the problems of interethnic conflicts get the most rigid form. Russian President Vladimir Putin believes that interethnic conflicts, most often, are the result of failures in education. Today the role of education is not limited only to the concept of "education itself". Its main function is the socialization of the individual. Socialization processes, developing today on the level of micro, form of common cultural norms and ideals, which are transformed into concrete rules of conduct. As a result, a particular hierarchy of values is developed. In his article, the authors have tried to highlight the most important functions of education, which contribute to the formation of this special value hierarchy.
\end{abstract}

Keywords: Education, youth, culture, tolerance, inter-ethnic relations;

\section{Introduction}

Entering into a new age of development, human civilization faced the phenomenon of globalization that swept not only mastered all mankind regions, but the main spheres of social life. The processes occurring under the influence of this phenomenon even in a greater degree "exposed" problems in the social, economic, political spheres of life in many countries of the world community, which significantly affected the level of social tension. The problem of social tension that grows increasingly into inter-ethnic conflicts, obtaining "ethnic colouring", destructively influence on national security. After the collapse of the Soviet Union on the territory of such a multi-ethnic state as the Russian Federation, inter-ethnic conflicts were not uncommon. The ethnic factor is increasingly becoming a cause of violence and aggression. Significantly increased in the twenty-first century attention to the question of stabilization of inter-ethnic relations has intensified the need to develop new skills of interethnic interaction. For this ethno-political risks associated with the revival or suppression of national identity, historical, ethnic and cultural unity of the different entities should be considered when developing such skills. Modern Russian state is necessary in real life to ensure equal rights and opportunities for all its citizens. For this the ethno-political risks, associated with the revival or suppression of national identity by historical, ethnic and cultural unity of the different entities, should be considered when developing such skills. Modern Russian state is necessary in real life to ensure equal rights and opportunities for all its citizens. This will ensure the establishment of stable and good ethnic relations that educate in citizens respect and tolerance towards others. In a multi-ethnic region, which is the southern region of Russia, ethical values play a significant role in the development of interethnic relations. The main difficulty in the way of harmonization of interethnic relations in the region, according to the authors A. S. Razin, T. P. Dneprov, A. L. Strizov, is the absence of the values and meanings that are significant for the formation of a positive image of interethnic relations in the minds of the people. The main role in shaping of values, preferred not only for society but also for the person, belongs to education. 


\section{Literature Review}

The value of education, considered from different perspectives: social, economic, personal, in our opinion, lies in the socialization of the individual. In his ability to understand the culture of modern society and consciously act in its framework, inheriting the sociocultural experience of previous generations. The determination of the content of education is connected with the development stages of social practices. It is necessary to clearly present the image of man, on which the educational concept will be oriented. In his work "Sense of history" Russian philosopher N. A. Berdyaev wrote: "Every person according to his inner nature there is a great world - a microcosm, in which reflects and residesis the whole real world and all the great historical epochs; he represents some of the passages of the universe, which concluded this little piece, he is a certain world that may be due to the state of mind of this man is still closed, but with the expansion and enlightenment of his mind is inwardly revealing." (Rodigina, I.C., 2000).

F. Mayor, UNESCO Director-General in his time, clearly outlined the main tasks of education:

- teaching of understanding of the necessity of non-violence;

- instilling of ideas of altruism and respect for others;

- formation of the ability to recognize the multiplicity of human existence in different cultural and social contexts

According to A. V. Lunacharsky "An educated person is a person in which the image of man is dominating." In research of A. P. Bulkina states: "The purpose of education is in the education itself,in the form of an image of a man with certain characteristics". (Bulkin, A.P., 2001).

J. Delor in his report at the session of the UNESCO already in 1996 has noted the "unprecedented growth of knowledge and the ability of a person to master them" (Delor, J., 1996).

With the change of the paradigm of social development at the turn of XX-XXI centuries, people is recognized as the supreme value, and the condition of his self-organization and self-development is the culture. The works of $L$. $V$. Vygotsky, S. A. Rubinstein, A. N. Leontiev became important milestones of scientific thought about the new modern understanding of human rights and the role of culture in his life. Among the pedagogical theories that emerged in the modern concept of social development of the Russian society, the concept of multicultural education of O. C. Arakelyan, G. J. Dautova, S. C. Rykova and concepts of multicultural education of H. A. Malkova, F. M. Malxasova, G. V. Palatkina, V. I. Suprunova, A. V. Shakfikava should be noted.

Methodological basis of the reproduction and transformation of values, stabilizing inter-ethnic relations is the "Concept of spiritual and moral development and education of a Russian citizen". There are all conditions to solve problems for the preservation of the cultures of the nations of Russia, harmonious inter-ethnic relations, the consolidation of the Russian multi-ethnic, multicultural society in modern Russian education. For the first time in educational standards characteristics of graduates of each level of education are formulated in the specific form.

\section{Methods and Materials}

The system of education in general and the higher education in particular should play a qualitatively-defined, specific historical role in the reproduction and transformation of values, contributing to the stabilization of inter-ethnic relations. Insufficient attention to the long side of education the question of value orientations of young people, led to the loss or significant reduction in the need for such social and personal qualities as well as culture, tolerance, dialogue, etc. For a long time insufficient attention of education to the question of value orientations of young people, led to the loss or significant reduction in the need for such social and personal qualities as well as culture, tolerance, readiness for dialogue, etc. The importance of education in solving this problem is updated by increasing public demand for the restoration of positive inter-ethnic relations through the formation of a personality - carrier of humanistic, tolerant ideas in the system of these relations. Being one of the main social institutions contributing to the formation of life-meaning youth, education must be innovative-organized, in which the principles of tolerance and dialogue are not only way learning, but also the aim. It is necessary to take into account that generated innovative-organized formation of identity will not be isolated in its activities from the socio-economic and political processes of the state and the international community. Therefore, in the process of education it is necessary to consider the specific, individual personality characteristics, based on its originality and uniqueness. The most important role in the search for social mechanisms to improve inter-ethnic relations belongs to the regional systems of general and vocational education. Speaking about the role of education in terms of stabilization of inter-ethnic relations in the southern region, we offer not only the organization of the reproduction and transformation of the values, but also the consideration of the national cultures.

Regional educational environment, concentrating in himself the whole palette of different ethnic groups and religions, is designed to educate in young people of all categories the basic understanding of the world, humanistic 
stance, to form innovative behavior, tolerant personality (Ivanov, S.Y., 2002; and Popkov, C.A. and A.V. Cirjuesv, 2004).

The formation of innovative behavior of a person has become one of the priorities of the Russian system of education. According to S. L. Rubinstein, the behavior is a special form of activity: it is the behavior when the motivation of the actions from the subject plan goes to personal-social relations plan (both plans are inseparable: personal-social relationships are implemented through the subject relations) (Solodnikova, I.V., 2012).

According to the position A. N. Leontief, the behavior is nothing but the response of the person on the substantive content of the surrounding world, generating the process of interaction of personality with reality. (Leontiev, A.N., 2011). From the point of view of social conditionality behavior can be viewed as the actions of man in relation to society and other people, covered by their regulation of public morality and law. On this basis, we can conclude that the innovation content of the environment and its innovative orientation determines the innovative nature of a person's behavior.

From our point of view, the innovative behavior of University students is a proactive type of behavior, including the ability to perceive, create, and implement innovations, in time to get rid of outdated, impractical, experience, and creativity of the individual to transform the existing reality. Innovative behavior is a rejection of standardization of behavior and the individual's inner world, the actualization of free inquiry, of active creativity.

Being the most organized environment, education is able to work out the mechanisms for the formation of a truly tolerant person. Namely in schools, where intellectual potential of teachers is concentrated, it is necessary to cultivate in young people the idea of tolerance, to develop skills of intercultural dialogue and positive attitudes towards the "other".

According to the researcher Ivanova S. Y., formation of tolerant attitudes of consciousness in a multi-ethnic educational environment can occur through:

- change of the content of education and upbringing;

- the integration of a culture of tolerance in school subjects;

- the study of cultural and historical traditions;

- purposeful intellectual, moral and emotional development of learners in the context of national culture;

- formation among students understanding of the diversity and interaction of cultures;

- the internalization of the values, attitudes and norms of behavior inherent in the idea of tolerance;

- the development of respect for human rights;

- the cultivation of positive, non-violent methods of preventing and resolving conflicts (Rusakova, E., 2002).

The level of tolerance of each individual is determined primarily by its moral-ethical properties. High moral values contribute to the understanding of others ' views, habits, opinions.

To be active and effective entity of relations in a multiethnic society, the education system must take into account the spatial, temporal, social, and semantic components of the socio-cultural environment. According to the researcher Rusakova E., "today in our society there are disparate worldviews and values, leading to a split in the consciousness of the personality, which is unacceptable from an educational and from a political point of view" (Rusakova, E., 2002).

Today ethnic tension in society is not only a cause of mental incompatibility caused by multiculturalism, but insufficient attention of education for a long time to the cultural formation of the young generation. Restore function of positive human relations in modern society belongs to education, with "high liquidity and demand" on the labour market and social services. Numerous sociological studies confirm the public importance of education. After all, the more educated people there are in society, the higher the level of tolerance in society is. Tolerance is the key to the effectiveness of education in the reproduction and transformation of values that help to stabilize social security and the tension in interethnic relations

The principle of tolerance is the key to the effectiveness of education in the reproduction and transformation of values that help to stabilize social security and the tension in interethnic relations.

The southern region is very rich in cultural communities. Their diversity causes aspiration of ethnic groups to preserve their ethno-cultural identity. Regional phenomenon should become culture-saving and culture-developing factor. According to the Russian scientist C. M. Menjueva education approaches to culture as a national. Understanding the culture as the basis for education and upbringing, the education can be seen on the socio-cultural background. The need to conform upbringing and education based on individual, national, universal in human emphasized in $1956 \mathrm{~A}$. Diesterweg (Delor, J., 1996). The term "ethno-cultural education" reveals the basic aim of education, which consists in forming the personality - the bearer of the ideas of national-cultural and linguistic identities, approved by previous generations. In higher education the center for the formation of moral norms and traditions of the ethnic group is a student group. In time of studentship the harmony of interests with peers develops, there is an awareness of ethnic and cultural interests, the beginnings of multicultural education are conceiving. Higher education allows students not only to master the competencies of their chosen profession, but also to build up their ability to understand complex ethnic systems, form of ethno-cultural interests. Great importance in the development of the student's ideological and moral conviction plays 
tolerance. The idea of tolerance should be a "red line" in all programs of General studies, as their complex allows to create a sense of diversity and values of ethnic cultures. Having acquired knowledge about the culture, history, language, ethnic groups living in the southern region, youth easier agrees to dialogue, rarely shows aggression, intolerance towards each other. According to the results of many years of work with the student audience and the analysis of the socialization process in the course of interpersonal communication in such a multicultural environment, as the Russian studentship, the authors are convinced that a huge role in the formation of ethno-cultural interests of students play holidays: the Victory Day, Independence Day of Russia, the Day of unity of peoples of Russia and many others. They do not only enrich the emotional perception of the world, but also directly affect the ethnic identity of every one. At the conducting of other mass events: excursions, trips, competitions, CFI - an active impact on the emotions of the students take place. Communication skills, the ability to understand and accept people of other ethnic groups are developing through emotional contact.

The importance of multicultural education in stabilization of regional inter-ethnic relations is widely disclosed in V. G. Dmitriev's work "Multicultural education".

«Multicultural education is education that aims to preserve and promote the diversity of cultural values, norms, patterns and forms of activity that exist in a particular community, in the public system and civilization as a whole, such as intercultural understanding and respect"( Rusakova, E., 2002).

We foster a multicultural identity by forming ethno-cultural interests of students, instilling in them the idea that each of them is valuable for a multiethnic state.

Russian culture, including the culture of other nations, played a decisive role in the perception of the idea of tolerance in multicultural region. According to D. S. Likhachev, Russian culture "is universal and tolerant to other cultures". (Likhachev, D.C., 1990).

The doctrine of national relations in the XXI century the ideology of tolerance is central. When searching and coordinating of common interests mutual understanding in inter-ethnic relations, excluding any pressure on representatives of other ethnic groups, is achieved. The main traditions of Russian education have always been patriotism, morality, democracy. It is primarily addressed to the person, instilling in him a personality, capable of a conscious and responsible choice in all situations of life, realizing his life purpose and his place in society. As a historically changing concept the education is able to reorient its goals and functions, changing educational structures.

The system of education will have to solve two interrelated problems: the formation of Russian national identity on the basis of co-citizenship and positive ("normal") ethnic identity, combining the positive perception of the history and culture of their ethnic group, while respecting and understanding the values of the cultures of other ethnic groups. (Musayev, I.M., 2006).

The education of youth in the spirit of understanding of the values of modern society, the adoption of these values is one of the most important and complex functions of education. The more humanity thinks about the importance of education in his life, the deeper reveals his abilities as a communicative tool.

In addition to cultural, educational and tolerant functions the education today largely determines attitudes and value orientations of individuals, and, more specifically, the society of the future depends on meaningful ideas and values that are placed in the educational program. Due to its universality, the education is the core of humanistic practice, different media systems and relationships that promote conflict-free integration of Russian society in the global cultural space. The system of education has great potential in the spiritual and moral education of youth. Spiritual values can cause conflicts, ling in the substantial divergence of cultural, religious, moral attitudes between ethnic groups. Virtually any conflict derives the internal mental world of man.

The increased interest to the problem of spiritual and moral education of youth in the conditions of a modern Russian society is caused primarily by the needs of the social practices associated with communication and interpersonal interaction. All-round personality development is influenced by the development of public relations, including a change of values. Change of values is characterized by a number of different phenomena, among which we can mention:

- the violation of the spiritual unity of society through rapid dismantling of the Soviet ideology and hasty copying of Western ways of life;

- the growth of violence and terrorism, social and ethnic conflicts, intense social, economic, ideological atmosphere;

- the erosion of moral values of the young generation and the devaluation of the values of the older generation;

- deformation of traditional for country moral standards and moral attitudes;

- a new "socio-cultural situation, which, in it turn, led to the decline of aesthetic education of children and youth, the unavailability of a number of cultural values for the majority of the population, to the collapse of the successfully functioning in the Soviet period system of cultural-educational work, to commercialization 
recreational and entertaining areas" (Bulkin, A.P., 2001).

Spiritual and moral development and education of the citizen are most effectively implemented in the period of studentship, because this age is the most sensitive to the absorption of socially significant. On moral beliefs, priorities in life, moral standards and spiritual values of today's youth depends the nature of the development of society.

Expanding introduction of innovative technologies in the educational space of the University places high demands on the organization of educational work among students in the spiritual and moral aspects. M. E. Merezhko in his researches of the relevance of the problem of spiritual and moral education of youth mixed up with the following regulations:

- first of all, our society needs to prepare well-educated, highly moral people who possesses not only knowledge, but also a great personality traits;

- secondly, in the modern world, the young man is living and growing, surrounded by a multitude diverse sources of strong exposure on him of both positive and negative character, which, of course, have an impact on not fully formed sphere of morality;

- $\quad$ thirdly, by itself, higher education does not guarantee a high level of moral education, because good manners is a quality of personality that determines in everyday human behaviour, his attitude towards others on the basis of respect and kindness to each person. Konstantin Ushinsky, the greatest Russian teacher, wrote: "the moral Influence is the main task of education";

- fourth, the armament of moral knowledge is important also because they do not only inform about the standards of behavior, approved in the modern society, but also give an idea about the consequences of the rules breaking or the consequences of this act for others". (Merezhko, M.E., 2011).

\section{Conclusions}

Reflecting on the role of education in the stabilization of inter-ethnic relations in the modern post-industrial Russia, one comes to an understanding of education as a specialized system that promotes to transform society into a unified system of human values by the regularities of its development. Culture, tolerance, ability to dialogue are qualities, the formation and development of which are the most important functions of education.

Today the role of education is not limited only to the concept of "education itself". Its main function is the socialization of the individual. Socialization processes, developing today on the level of micro, form of common cultural norms and ideals, which are transformed into concrete rules of conduct. As a result, a particular hierarchy of values is developed. In his article, the authors have tried to highlight the most important functions of education, which contribute to the formation of this special value hierarchy.

In conclusion, the education system in the world today, due to its functions its functions, plays an integrative role in the formation of social communities, social institutions of society, the formation of an interactive personality. Education is the only institution of society, upon which the greatest number of relationships between social communities and their representatives. Education prepares for mankind ready patterns of behavior and the opportunity to develop their obuslavivaet. It is due to the formation of exchange of knowledge, information, and, consequently, opportunities between social strata, between groups, states, people; so carried communicative function of education. Any function of education cause interaction, integration into society, which leads to the humanitarian function of education, from which all the other functions of the institution of education, the role and importance in society is very important.

An important function of education is systematic training and education of members of a society focused on the acquisition of certain knowledge (especially scientific), the ideological and moral values, skills, rules of conduct, the content of which is determined by socio-economic and political relations of society, the level of its logistics development.

\section{References}

Rodigina, I.C., 2000. Humanization and humanitarization of science education in schools: Lugansk. 32 pp. Bulkin, A.P., 2001. Socio-cultural dynamics of education. Dubna. 143 pp.

Delor, J., 1996. Education: hidden treasure/J. Delor. UNESCO. 128 pp.

Rusakova, E., 2002. Intolerance and hostility in the Russian society/E. Rusakova. Moscow: Nauka. 84 pp.

Likhachev, D.C., 1990. About the national character of Russians//Questions of philosophy. No. 4. 3-6 pp.

Musayev, I.M., 2006. Social identity of the person and its ethnic component/the Reality of the ethnic group. The role of education in shaping ethnic and civil identity. Materials of VIII International scientific-practical conference/Under the scientific editorship of I. A. Nabok - SPb. 71 pp.

Ivanov, S.Y., 2002. Formation of tolerant attitudes of consciousness in a multi-ethnic educational environment// the Social order and 
tolerance: Proceedings of the III all-Russian scientific conference.

Popkov, C.A. and A.V. Cirjuesv, 2004. Theory and practice of higher education. Moscow.

Merezhko, M.E., 2011. Analysis of the problems of moral upbringing of students //domhors.ru/issue/fik/2011-3-4/merezhko.pdf.

Solodnikova, I.V., 2012. Socialization: nature and characteristics at different stages of life / I. V. Solodnikova // Sociological research № 2. $78 \mathrm{pp}$.

Leontiev, A.N., 2011. Activities. The consciousness. The behavior. Moscow: Politizdat. 251-253 pp. 